\title{
ANALÜÜTILISTE JA SÜNTEETILISTE KOHATARINDITE VAHEKORD 17.-18. SAJANDI PÕHJAEESTI KIRJAKEELES ${ }^{1}$
}

\author{
LIINA PÄRISMAA
}

Annotatsioon. Artikli eesmärk on välja selgitada muutused kohatähenduse väljendamisel 17.-18. sajandi jooksul, lähtudes tarindite analüütilisusest-sünteetilisusest. Vaadeldakse kaassõnade ja käändevormide suhet kohatähenduse väljendamisel põhjaeesti kirjakeele kiriklikes tekstides, keskendudes substantiividega mägi, tee, linn, haud, meri, Jeruusalemm, süda, taevas, raamat, kõrb ja maa moodustatud kohatarinditele. Eritähelepanu on 17. sajandi keskpaiga uuendusmeelse kirjamehe Christoph Blume vormikasutusel. Materjal pärineb Tartu Ülikooli vana kirjakeele korpustest ja Eesti Keele Instituudi eesti piiblitõlke ajaloolisest konkordantsist. Uurimistulemused näitavad 17. sajandi lõpukümnenditel alanud kirjakeele reformist alates sünteetiliste kohatarindite osakaalu suurenemist ja analüütiliste oma vähenemist. Sõnuti kalduvad sünteetilise kohatähenduse väljendamise poole üheteistkümnest substantiivist kaheksaga moodustatud konstruktsioonid. Christoph Blume eelistab oma teostes analüütilisi kohatarindeid, kuid sünteetiliste kohatarindite kasutuselevõtmisel ilmneb tema tekstides riimilise sobivuse taotlus.

Võtmesõnad: vana kirjakeel, morfosüntaks, kohakaassõnad, kohakäänded, eesti keel

\section{Sissejuhatus}

Siinne artikkel moodustab ühe osa ulatuslikumast uurimusest, mille eesmärk on täpsustada eri tüüpi morfosüntaktiliste nähtuste põhjal 17.-18. sajandi põhjaeesti kirjakeele kujunemise dünaamikat ja kirjeldada saadud tulemuste alusel ajastu keele üldpilti. Käsitluses keskendutakse

\footnotetext{
Artikli valmimist on toetanud Euroopa Regionaalarengu Fond (Eesti-uuringute Tippkeskus) ja Eesti Teadusagentuur (projekt PRG341).
} 
kaassõnade ja käändevormide suhtele kohatähenduse väljendamisel. Materjali allikas on 17.-18. sajandi põhjaeesti kirjakeele tekstid.

17.-18. sajandi põhjaeesti kirjakeel oli mõjutatud saksa keelest ja selles leidus mitmeid saksapärasusi, nt saama-tulevik, mitte-eitus, saksapärane artiklikasutus (Metslang 1994: 542; Habicht 2001: 32; Pärismaa 2018). Ka kaassõnade eelistamist käändevormidele on peetud saksapäraseks nähtuseks (vt nt Aavik 1936: 92; Palmeos 1985: 15, 21; Ziegelmann, Winkler 2006: 57). 17. sajandi lõpukümnenditel hakati aga põhjaeesti kirjakeelt uuendama (Ross 2013: 212), mille tulemusena vähenesid saksaeeskujulised jooned (nt saama-tulevik) ja sagenesid eesti keelele omased jooned, nt taandus mitte-eitus ja esile tõusis ei-eitus, vähehaaval lisandus võtmatulevik (vt nt Pärismaa 2018, 2019). Seega on tollane aeg eesti kirjakeele arengu seisukohalt huvitav ning pakub mitmekülgset uurimismaterjali, sh kohatähenduse väljendamise kohta, mille uurimine võib täpsustada 17. sajandi lõpu kirjakeele reformi kulgu.

Siinses uurimuses keskendutakse 17.-18. sajandi põhjaeesti kiriklikele tekstidele, et näha, kas samamoodi nagu siinkirjutaja varasemates morfosüntaktilisi nähtusi käsitlevates uurimustes (vt Pärismaa 2018, 2019) avaldub ka vaatlusalustes kohatarindites suundumus saksapärasuste vähenemisele. Eesmärk on välja selgitada, kas ja mil moel muutub kohatähenduse väljendamine põhjaeesti tekstides kahe sajandi jooksul. Eeldatakse, et põhjaeesti kirjakeele reformimise ajast alates suureneb vaimulikes teostes sünteetiliste vormide osakaal ja väheneb analüütiliste oma. Oletatakse ka, et varasemate tekstidega võrreldes ilmneb analüütilisi tarindeid vähem juba 17. sajandi keskpaiga autoril Christoph Blumel, kelle teostest on leitud uuenduslikke vorme (vt nt Pärismaa 2018).

Kaassõnade ja käändevormide kasutuse vahekorda eesti vanas kirjakeeles on seni käsitletud vähe. Külli Habicht ja Helle Metslang (2015) on eri etappide kirjakeele analüütilisuse ja sünteetilisuse suhte uurimisel pööranud tähelepanu ka kaassõna peal ja alalütleva käände vahekorrale. Nende ettekandest selgus, et eesti vanema kirjakeele ajajärgul valitsesid analüütilised tarindid, ent 19. sajandiks oli sünteetiliste tarindite osatähtsus mõnevõrra suurenenud (Habicht, Metslang 2015). Üliõpilastöödes on analüütilistele ja sünteetilistele tarinditele vähesel määral tähelepanu pööranud siinse artikli autor, kelle magistritööst ilmnes, et erinevalt varasematest põhjaeesti autoritest kasutas Blume osa sõnadega (nt värav) ainult sünteetilisi asukohatarindeid (Pärismaa 2016: 41-42). Külli Habicht (vt nt 2000: 
$23,51)$, kes on uurinud adpositsioonide grammatiseerumist, on viidanud saksa keele mõjule adpositsioonide sagedasel kasutamisel eesti vanemas kirjakeeles. Kristiina Ross (1997: 198-199) on kohakäänete kasutust Mülleri ja Stahli tekstides võrreldes leidnud kahel autoril sarnasusi, nt siht- ja asukoha väljendamine kaassõnatarindiga. Helle Metslangi jt (2017: 160) empiirilisest uurimusest komitatiivi funktsioonide kohta eri aegadel ja registrites on ilmnenud, et kui 17. sajandi I poole tekstides kasutatakse põhiliselt sõnaga kaas moodustatud komitatiivset adpositsioonifraasi, siis 18. sajandil juba ainult komitatiivi käändelõpuga varianti. Siinses artiklis vaadeldakse kohatähenduse (siht-, asu- või lähtekoha) paralleelset edasiandmist kaassõnade ja käändevormidega.

Artikli järgmises jaotises tutvustatakse kaassõnade ja käändevormide esitust 17.-18. sajandi põhjaeesti keelekäsitlustes. Teises osas kirjeldatakse töö uurimismeetodit ja materjali. Artikli kolmandas jaotises esitatakse uurimistulemused ja neljandas nende põhjal tehtud üldistused.

\section{Kohakaassõnad ja -käänded 17. sajandi ja 18. sajandi I poole põhjaeesti keelekäsitlustes}

Kohta väljendavaid kaassõnu ja käändeid käsitleti 17. sajandi ja 18. sajandi I poole põhjaeesti grammatikates erineval määral. Siinses uurimuses vaadeldavasse ajajärku jäid põhjaeesti grammatikatest neli: Heinrich Stahli „Anführung zu der Esthnischen Sprach, auff Wolgemeinten Rath, und Bittliches Ersuchen“ (1637), Heinrich Gösekeni „Manuductio ad Linguam Oesthonicam“ (1660), Johann Hornungi „Grammatica Esthonica, brevi, Perspicua tamen methodo ad Dialectum Revaliensem“ (1693) ning Anton Thor Helle ja tema kaasautorite „Kurtzgefaszte Anweisung Zur Ehstnischen Sprache“ (1732).

Heinrich Stahl lähtub oma 1637. aasta keeleõpetuses „Anführung zu der Ehstnischen Sprach“ ladina keele grammatikate eeskujust (Rätsep 1987: 713-714) ja nimetab kõiki adpositsioone ladina eeskujul prepositsioonideks. Samas märgib ta, et neid võib nimetada ka postpositsioonideks, kuna enamasti need järgnevad substantiividele. Kohakaassõnadest on ta esile toonud sisekohta märkivad sisse, sees ja seest. (Stahl 1637: 32) Väliskohta märkivaid adpositsioone pole ta aga prepositsioonide nimekirjas esitanud. Samuti ei leidu neid adverbide käsitluse juures. 
Käändeid on Stahli grammatikas kuus (nominatiiv, genitiiv, daativ, akusatiiv, vokatiiv, ablatiiv). Eraldi osana esitab ta nimi- ja asesõnade käänamise ning omadussõnade käänamise koos nimisõnadega, millest igaühe juures on näiteid nii ainsuse- kui ka mitmusevormide kohta. Genitiiv on Stahlil vasteks tänapäeva elatiivile, nt öhest Jummalast, daativ on vasteks adessiivile, nt öhel Jummalal, ning sama käände mitmusevorm allatiivile, nt öhelle Jummalalle. Alaltütlev kääne märgib nii seest- kui ka alaltütlevat käänet, nt öhest Jummalast / öhelt Jummalalt. (Stahl 1637: 4-9) Illatiivi ega inessiivi Stahl käändeid käsitlevas osas pole nimetanud.

Heinrich Göseken käsitleb oma grammatikas „Manuductio ad Linguam Oesthonicam“ (1660) adpositsioone mõnevõrra põhjalikumalt kui Stahl, nt eristab ta tähelisi (st käändetunnuseid) ja sõnalisi prepositsioone, nt ollen tallinas, ollen tallina sees. Samamoodi nagu tänapäevastes käsitlustes (vt Veismann, Erelt 2017: 446) märgib ka tema, et täheline prepositsioon väljendab kohta üldisemalt ja sõnaline täpsemalt. (Göseken 1660: 71; Kingisepp jt 2010: 251) Kohakaassõnadest esinevad Gösekeni keelekäsitluses sisse, sees, peale ja peal (Göseken 1660: 42, 71-72). Adpositsioone seest ja pealt ei ole ta nimetanud, samuti pole Göseken neid esitanud adverbide loendis. Kaassõnu seest ja pealt leiduski tollastes tekstides harvem kui muid kaassõnu, nt sisse esineb kaassõnana vana kirjakeele korpuste (VAKK) 17. sajandi põhjaeesti tekstides 2021 korral, seest vaid 80 korral. Samas esitab Göseken täheliste prepositsioonide juures elatiivi tunnuse -st, nt ma tulen linnast (Göseken 1660: 72).

Käändeid on Gösekeni grammatikas nagu Stahlilgi kuus (nominatiiv, genitiiv, daativ, akusatiiv, vokatiiv, ablatiiv) ning nende tunnused kattuvad Stahli esitatutega. Samas käsitleb ta käändeid mõnevõrra põhjalikumalt kui Stahl, tehes märkusi selle kohta, millele lugeja peab käänamisel tähelepanu pöörama, ja loetledes mõnel juhul ka erandeid. Eraldi osana on Gösekeni grammatikas esitatud substantiivide ja pronoomenite käänamine, adjektiivide kohta on mõned näited substantiive käsitlevas osas. (Göseken 1660: 26-30, 33-36)

Erinevalt kahest varasemast keelekäsitlusest on Johann Hornungi „Grammatica Esthonica“ (1693) prepositsioonide osas esitatud kõik siinses uurimuses käsitletud sise- ja väliskohta väljendavad adpositsioonid: sisse, sees, seest, peal, peale ja pealt, nt wanna Naene läks Ahjo päle soja (Hornung 1693: 105-106). Samuti erineb Hornungi grammatika käänete esitus kahe varasema keelekäsitluse omast. Käändeid nimetab ta 
viis: nominatiiv, genitiiv, daativ, akusatiiv ja ablatiiv, välja on ta jätnud vokatiivi. Genitiiv ei tähista enam elatiivi, vaid genitiivi, nt Jummala, ning daativ vastab allatiivile ja adessiivile. Ablatiiv võib märkida Hornungil nelja tänapäevast kohakäänet: elatiivi, ablatiivi, illatiivi ja inessiivi, nt Taewast, Jummalasse. (Hornung 1693: 13-14, 18)

Samamoodi nagu Hornungi grammatikas, on ka Anton Thor Helle jt keelekäsiraamatu „Kurtzgefaszte Anweisung Zur Ehstnischen Sprache““ (1732) prepositsioonide peatükis esitatud kõik kuus kohta tähistavat kaassõna: sisse, sees, seest, peale, peal ja pealt. Helle jt teoses rõhutatakse, et prepositsioonide kohta peaks ütlema postpositsioonid, sest need paiknevad põhiliselt sõna järel. (Helle jt 1732: 59) Sama on täheldanud ka Stahl oma käsitluses (vt Stahl 1637: 32).

Erinevalt Hornungi grammatikast ning sarnaselt Stahli ja Gösekeni käsiraamatutega esineb Helle jt keelekäsitluses kuus käänet: nominatiiv, genitiiv, daativ, akusatiiv, vokatiiv ja ablatiiv. Lisaks toovad Helle jt välja 17 klassi jaotatud erandid. Samas, nii nagu Hornungil, vastab genitiiv ka Helle jt teoses genitiivile, daativ allatiivile ja adessiivile ning ablatiiv nii elatiivile kui ka tänapäeva ablatiivile, nt linnadest. (Helle jt 1732: 12-20)

\section{Materjal ja meetod}

Uurimuse materjal pärineb Tartu Ülikooli vana kirjakeele korpustest (edaspidi: VAKK) ja Eesti Keele Instituudi eesti piiblitõlke ajaloolise konkordantsi sõnastikuosast (edaspidi: EPAK). 17. sajandi põhjaeesti aines koguti uuest VAKKist ${ }^{2}$ ja Müncheni käsikirja puudutav osa EPAKist ${ }^{3}$. 18. sajandi põhjaeesti materjal on nii VAKKi uuemast kui ka varasemast versioonist ${ }^{4}$.

17. sajandi põhjaeesti vaimulikest teostest uuriti Georg Mülleri jutlusi (1600-1606), Heinrich Stahli teoseid „Hand- vnd Haußbuch“ I-IV (1632-1638) ja „Leyen Spiegel“ I-II (1641, 1649), Christoph Blume teoseid „Das Kleine Corpus Doctrinæ“ (1662), „Geistliche Wochen-Arbeit“ (1666) ja „Geistliche Hohe Fäst-Tahgs Freude“ (1667) ning Müncheni piiblitõlkekäsikirja (1694), mille autoriks peetakse Johann Hornungit

\footnotetext{
2 vakk.ut.ee.

3 http://portaal.eki.ee/piibel.

${ }^{4}$ http://www.murre.ut.ee/vakkur/Korpused/Kwic2/paring.htm.
} 
(Reila 2007: 556). 18. sajandi põhjaeesti kiriklikest teostest vaadeldi 1715. aasta uut testamenti ja 1739. aasta piiblit. Viimasega neist tipnes tollane reformitud kirikukirjakeel (Ross 2009: 557).

17. sajandi I poole põhjaeesti teoste puhul tehti otsing VAKKi uuema versiooni märgendatud osast, kus Georg Mülleri jutlustes on eestikeelseid sõnesid 99 160, Stahli tekstides kokku 322195 ja Blume teostes kokku 34 954. Müncheni käsikirja maht vaadeldud 11 sõna korral on 51297 sõnet. 1715. aasta uue testamendi ja 1739. aasta täispiibli kohta tehti uues VAKKis sõneotsing, mitte märksõnaotsing, kuna need tekstid on osaliselt märgendamata. Uue VAKKi 1715. aasta uues testamendis on eestikeelseid sõnesid 112701 ja 1739. aasta täispiiblis 604 574. VAKKi varasemas versioonis on 1715. aasta uue testamendi sõnede arv 118545 ja 1739. aasta täispiibli sõnede arv $159256 .{ }^{5}$ Et kontrollida sünteetiliste ja analüütiliste kohatarindite kasutust edasistel ajajärkudel, tehti korpusotsing VAKKi 19. sajandi tekstidest ja korpusest etTen $\operatorname{Ten}^{6}$, mis sisaldab tänapäevaseid eestikeelseid veebitekste, nt foorumitest või ajalehtedest.

Kokku uuriti kohatähenduse väljendamist 18 sõnal, millest lõppvalikusse jäi 11: meri, Jeruusalemm, süda, taevas, raamat, linn, kõrb, haud, mägi, tee ja maa. Taustaks vaadeldi nende sõnade kõigi käändevormide ja kaassõnade suhet. Kohatähenduse väljendamist uuriti sõnade kaupa ega võetud korpustest kõigi käändevormide ja vastavate kaassõnade sagedusi, et säilitada materjali hulga piiramise kaudu selle võrreldavus. Materjali hulka oli vaja piirata, kuna 17. sajandi ja 18. sajandi I poole põhjaeesti autorite tekstide maht on suur ${ }^{7}$ ning nende läbivaatamine oleks kujunenud väga ajamahukaks. Näiteks Stahli tekstides leidub elatiivivorme 9978 korral, 1739. aasta täispiiblis esineb sees 1110 korral (nii kaassõna kui ka adverbina) (VAKK). Kõigist korpustest otsingu vastuseks tulnud aines tuli läbi töötada käsitsi, et välistada teised tähendused peale kohatähenduse, nt PÕHJUS või ADRESSAAT. Üldine statistika korpuste kogumahu pealt sellist eristust teha ei võimaldaks.

Uurimusse sooviti valida sõnad, milles oleksid kohatähenduse vormid võimalikult mitmekülgselt esindatud ja mis moodustaksid kõigil või enamikul uuritavatel autoritel kohakäändevormi ja kaassõnafraasi paari, samuti võeti arvesse sagedust. Materjali kogudes ilmnes, et kõiki neid

5 Seisuga 25.03.2020.

${ }^{6}$ keeleveeb.ee.

7 Vt praegusest peatükist nt Stahli tekstide või 1739. aasta täispiibli sõnede koguarvu. 
kriteeriume pole võimalik täielikult arvestada. Sõna võis küll tekstides sagedasti esineda, kuid kohatähendust väljendati sellega autoriti ebaühtlaselt või ei kasutatud kaassõna ja käändevormi paralleelselt. Näiteks esineb siinses uurimuses vaadeldud 17.-18. sajandi põhjaeesti tekstides sõna kirik 486 korral, kuid kolme autori peale on selle sõna elatiivivormiga antud lähtekohatähendust edasi vaid 12 korral ning mitte ühtegi korda pole selleks kasutatud adpositsiooni seest (VAKK). Vormivahendite võrreldamatuse tõttu ei annaks selline sõna teavet analüütiliste ja sünteetiliste tarindite vahekorra kohta. Samuti ei olnud võimalik jälgida kohatähenduse väljendamist kõigis ühe sõna käände-kaassõna paarides, kuna neid paare alati ei esinenud. Näiteks anti sõna meri puhul asukohatähendust edasi adpositsiooniga peal, kuid adessiivi selleks ei tarvitatud. Samuti ei leidunud sõnaga meri tarindites ühtegi ablatiivi ega adpositsiooniga pealt moodustatud lähtekohavormi.

Vaatlusalusest materjalist ilmnes samuti, et väliskohakäänete ja -kaassõnade abil väljendatakse kohta sisekohakäänetega võrreldes harvem. 17.-18. sajandi põhjaeesti teostes neid küll tarvitatakse, kuid põhiliselt muu tähenduse kui koha väljendamiseks, nt OMAJA või KOGEJA. Nii on 17. sajandi põhjaeesti tekstides viie kõige sagedamini adessiivis esinenud sõna seas pronoomen see ja kolm personaalpronoomenit (mina, tema, sina). Vormivaliku eripära võib tuleneda ka tekstiliigist: siinses uurimuses vaadeldud materjal esindab religioosseid tekste, kus kohta on väljendatud peamiselt religioossetele tekstidele omaste sõnadega, nagu taevas (928 esinemust), kuid vähesel määral või üldse mitte nt olmeliste sõnadega, nagu tool (5 esinemust) (VAKK).

Materjali käsitlemisel oli teoreetiliseks aluseks kasutuspõhine teooria. Kasutuspõhise teooria keskmes on keelekasutusjuhud, mille põhjal kujuneb kasutaja keelesüsteem ja mis seda ka edaspidi mõjutavad (Barlow, Kemmer 2000: viii; Bybee 2010: 14). Keskendumine keelekasutusele võimaldab uurimusse haarata eri tüüpi materjali ning seega tähelepanu pöörata eri aegade keelemuutustele, avades neid paremini ka autorite tasandil (Bybee 2010: 10). Siinses uurimuses toetas kasutuspõhine teooria toimunud muutustest laiema pildi kujunemist, kuna ei keskendutud tollaste kirjameeste keeleoskusele, vaid tekstides kasutatud keelekujule. 


\section{Analüütiliste ja sünteetiliste kohatarindite vahekord}

Analüütiliste ja sünteetiliste vormide suhe kohatähenduse väljendamisel uuritud 11 sõnas on näha joonisel 1. Üldise tendentsina ilmnes sünteetiliste kohatarindite kasutuse suurenemine aja jooksul. Kui 17. sajandi I poole põhjaeesti autorite Mülleri, Stahli ja Blume tekstides oli sünteetilisi kohakonstruktsioone 21-35\%, siis sama sajandi lõpupoolel Müncheni käsikirjas (edaspidi joonistel: Münch.kk) juba 80\%. 1715. aasta uues testamendis (edaspidi joonistel: UT 1715) ja 1739. aasta täispiiblis (edaspidi joonistel TP 1739) oli sünteetiliste kohatarindite osakaal vastavalt 73\% ja $68 \%$. Seevastu analüütiliste kohatarindite osakaal oli Mülleri jutlustes $79 \%$, Stahli teostes $65 \%$ ja Blume töödes $71 \%$. Müncheni käsikirjas jäi analüütiliste kohakonstruktsioonide osakaal 20\% juurde, 1715 . aasta uues testamendis oli see $27 \%$ ja 1739 . aasta täispiiblis $32 \%$. Kokku kasutati vaadeldud 11 sõnaga tarindites kõiki käändevorme kohatähenduse väljendamiseks 4264 korral ja kaassõnu 2941 korral. Kui võtta analüütilisuse-sünteetilisuse vahekord kokku ainult tekstis käsitletud käänete-kaassõnade põhjal, siis selgub, et sünteetilisi vorme on 1679 ja analüütilisi 1087.

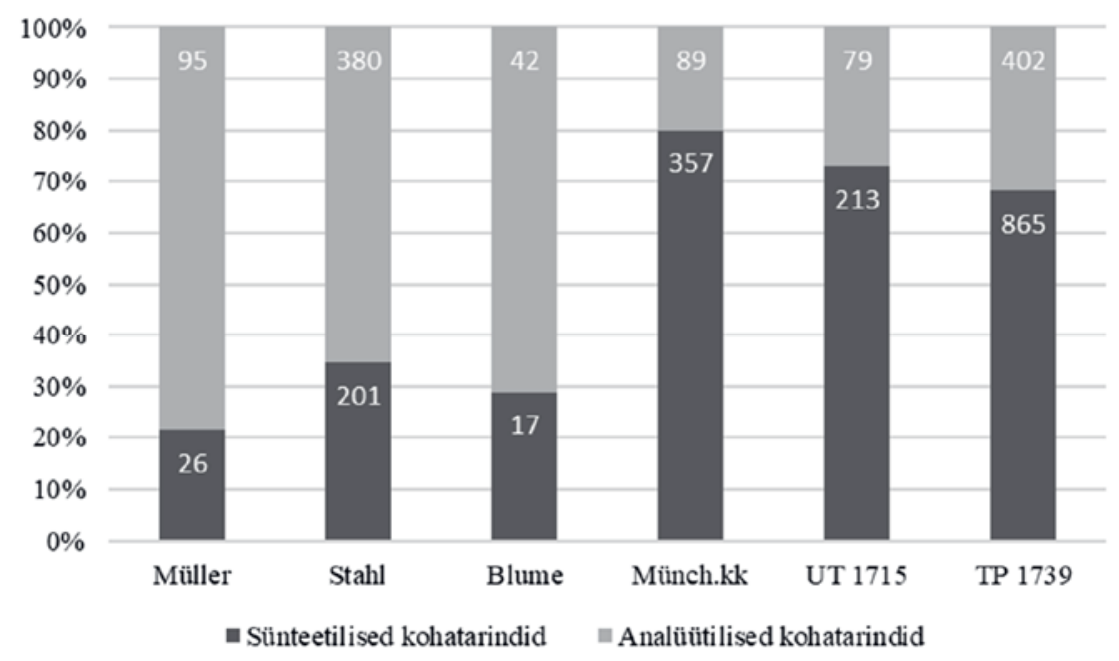

Joonis 1. Analüütiliste ja sünteetiliste vormide suhe 17.-18. sajandil 
Sõnuti ilmnes, et substantiivid koonduvad kahte gruppi vastavalt kohatähenduse väljendamise suundumusele: sünteetilisusele kaldus kaheksa sõna ja analüütilisusele kolm sõna. Seetõttu tutvustataksegi järgmistes jaotistes uurimistulemusi nende kahe grupi alusel.

\subsection{Sünteetilisusele kalduvad kohatarindid}

Uurimuses vaadeldud 11 sõnast kaldus kohatähenduse väljendamisel sünteetilisusele kaheksa: meri, Jeruusalemm, süda, maa, taevas, kõrb, raamat ja linn. Sõnadega meri, Jeruusalemm ja süda tarindites uuriti sihtkohatähenduse samaaegset väljendamist adpositsiooniga sisse ja illatiiviga, sõnaga maa sihtkohatähenduse väljendamist adpositsiooniga peale ja allatiiviga ning sõnadega taevas, kõrb, raamat ja linn tarindites asukohatähenduse samaaegset väljendamist adpositsiooniga sees ja inessiiviga. Sise- ja väliskohakäänete ning kaassõnade vahekorrast kohatähenduse väljendamisel annab ülevaate tabel 1 .

Tabel 1. Sise- ja väliskohakäänete ning kaassõnade vahekord sünteetilisusele kalduvates sõnades

\begin{tabular}{|c|c|c|c|c|c|c|}
\hline Sõna & Funktsioon & Kääne & Sagedus & Kaassõna & Sagedus & Kokku \\
\hline \multirow[t]{2}{*}{ meri } & Sihtkoht & Illatiiv & 40 & sisse & \begin{tabular}{|l|}
19 \\
\end{tabular} & 59 \\
\hline & & Allatiiv & 1 & peale & 14 & 15 \\
\hline \multirow[t]{2}{*}{ Jeruusalemm } & Sihtkoht & Illatiiv & 245 & sisse & 15 & 260 \\
\hline & & Allatiiv & 0 & peale & 4 & 4 \\
\hline \multirow[t]{2}{*}{ süda } & Sihtkoht & Illatiiv & 71 & sisse & 108 & 179 \\
\hline & & Allatiiv & 0 & peale & 8 & 8 \\
\hline \multirow[t]{2}{*}{ maa } & Sihtkoht & Illatiiv & 1 & sisse & 92 & 93 \\
\hline & & Allatiiv & 497 & peale & 231 & 728 \\
\hline \multirow[t]{2}{*}{ taevas } & Asukoht & Inessiiv & 303 & sees & 162 & 465 \\
\hline & & Adessiiv & 0 & peal & 0 & $\mathbf{0}$ \\
\hline \multirow[t]{2}{*}{ kõrb } & Asukoht & Inessiiv & 187 & sees & 23 & 210 \\
\hline & & Adessiiv & 0 & peal & 0 & 0 \\
\hline \multirow[t]{2}{*}{ raamat } & Asukoht & Inessiiv & 44 & sees & 32 & 76 \\
\hline & & Adessiiv & 0 & peal & 0 & $\mathbf{0}$ \\
\hline \multirow[t]{2}{*}{ linn } & Asukoht & Inessiiv & 193 & sees & 82 & 275 \\
\hline & & Adessiiv & 0 & peal & 1 & 1 \\
\hline
\end{tabular}


Analüütiliste ja sünteetiliste vormide suhet sünteetilisusele kalduvates kohatarindites näitlikustab kokkuvõtvalt joonis 2 . Alljärgnevalt vaadeldakse ainult neid kohatarindeid (sh joonistel), millel on piisavalt paralleelvorme, nt sõnaga linn tarindites väljendatakse asukohta vaid inessiivi ja adpositsiooniga sees. Eraldi ajana on nii siinses osas kui ka edaspidi esile toodud 17. sajandi lõpp, põhjaeesti kirjakeele reformi algusaeg, kuhu paigutub ka Müncheni käsikiri, sest varasemate uurimuste põhjal (vt nt Kilgi 2012) on sellest ajast alates ilmnenud vormikasutuses teravamad muutused.

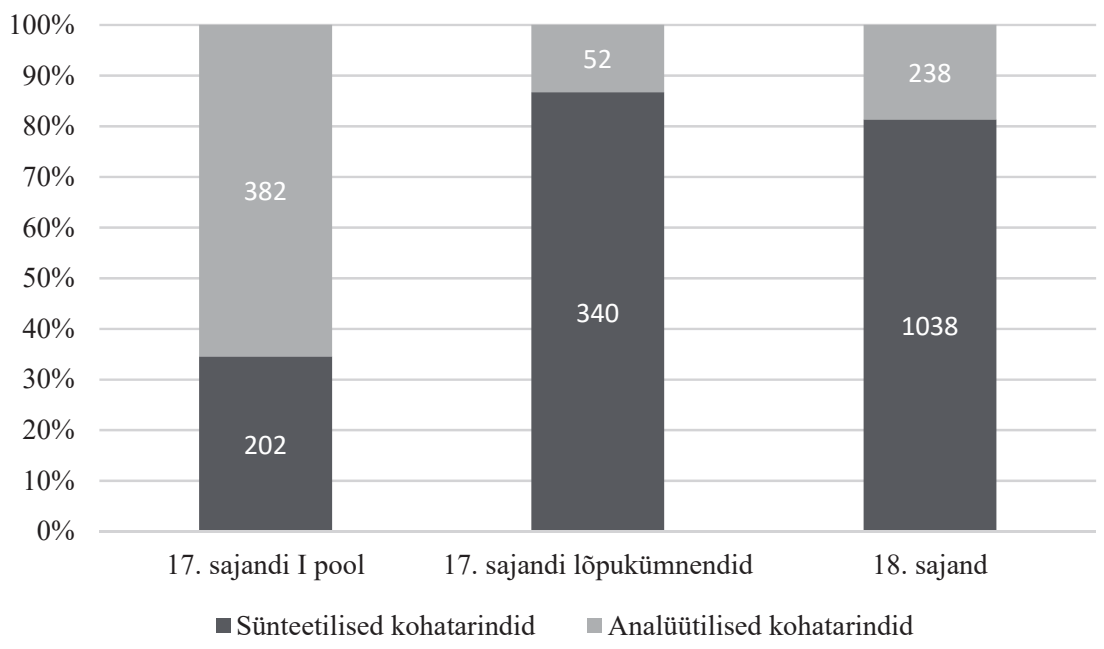

Joonis 2. Analüütiliste ja sünteetiliste vormide suhe sünteetilisusele kalduvates kohatarindites

Tulemustest selgus, et uuritava ajavahemiku jooksul muutus tollastes põhjaeesti tekstides koha väljendamine nende kaheksa sõna puhul sünteetilisemaks (1) ning selgem kasutusmuutus toimus alates 17. sajandi 1õpupoolest, põhjaeesti kirjakeele reformi algusest. 17. sajandi I poolel oli sünteetiliste kohatarindite osatähtsus põhjaeesti tekstides 35\%, 17. sajandi lõpukümnenditel $87 \%$ ja 18 . sajandi I poolel $81 \%$. Kohta väljendavate analüütiliste konstruktsioonide (2) osakaal oli vastavalt 65\%, 13\% ja 19\%.

(1) Minna ollen teile kirjotanud Ramatus, et teie ennast ei pea seggama Pordo-piddajadega. (EPAK, Münch.kk 1694: 1Kr 5:9) 
(2) .. Minna tahhan Jssandal laulda / sest Temma on öhe auwsa Töh têenut / Hobboset nink Töldat on Temma Merre sisse lükkanut'Tahan laulda Issandale, sest ta on teinud ühe ausa töö, hobused ja tõllad merre lükanud' (VAKK, Blume 1667: 12)

Mõnevõrra kõikuvam oli sünteetilisusele kalduvate kohakonstruktsioonide seas sõnaga linn moodustatud asukohatarindite vahekord (vt joonist 3). 17. sajandi algupoole põhjaeesti autori Mülleri jutlustes esines sünteetilisi ja analüütilisi asukohatarindeid peaaegu võrdselt, vastavalt $53 \%$ ja $47 \%$, seevastu sama sajandi keskpaiga autor Blume kasutas oma tekstides sõnaga linn tarindites ainult analüütilisi asukohta märkivaid tarindeid ning Stahli teostes moodustasid sõna linn puhul kaassõnaga väljendatud asukohatarindid $29 \%$ ja käändevormiga vormistatud tarindid $71 \%(3)$.

(3) .. Sest teña issi ütlep: Kus nemmat teid öhes Linnas perrenkiusawat / sihs pögkeneket se töise sisse. 'Tema ise ütleb: kui nad teid ühes linnas taga kiusavad, siis põgenege teise' (VAKK, Stahl 1641: 454)

Stahli tekstide keelekasutuses on mitmeid saksapärasusi (vt nt Habicht 2001: 32-33), seega võinuks eeldada, et tema töödes on ka sõna linn puhul ülekaalus kaassõnaga moodustatud tarindid. Võrreldes 17. sajandi alguse autori Mülleri jutlustega oli sünteetiliste asukohatarindite osakaal Stahli tekstides suurenenud sõnaga linn tarindites ligikaudu 20\%, mille põhjus võib olla kohatähenduse väljendamise vaba varieerumine tegelikus keelekasutuses. Kuigi tollal oli kiriklikus kirjakeeles juba mõningast ühtlust, leidus seal siiski ka varieeruvust (Lill 1988: 14-15, 17), mida näitab muu hulgas asukohta väljendavate vormide vahelduv kasutus Stahli tekstides. Sõnaga linn sarnane tulemus ilmnes nt sõna raamat kohta, mille korral oli Stahli tekstides sünteetiliste asukohatarindite osakaal analüütiliste omast $6 \%$ suurem. Samas sõna linn sihtkohatähenduse edasiandmisel domineerisid tal analüütilised tarindid, nagu ka sõnaga taevas asukoha väljendamisel.

Sarnaselt teiste sünteetilisusele kalduvate kohatarinditega valitsesid 17. sajandi lõpupoolest ka sõna linn puhul sünteetilised tarindid. Kuigi sünteetiliste ja analüütiliste konstruktsioonide osakaal 18. sajandi põhjaeesti tekstides kõikus mõnel määral, jäid ka siis valitsema sünteetilised konstruktsioonid, mis näitab, et uuritud ajavahemikul on sõna linn asukohatähenduse väljendamine stabiliseerunud. 


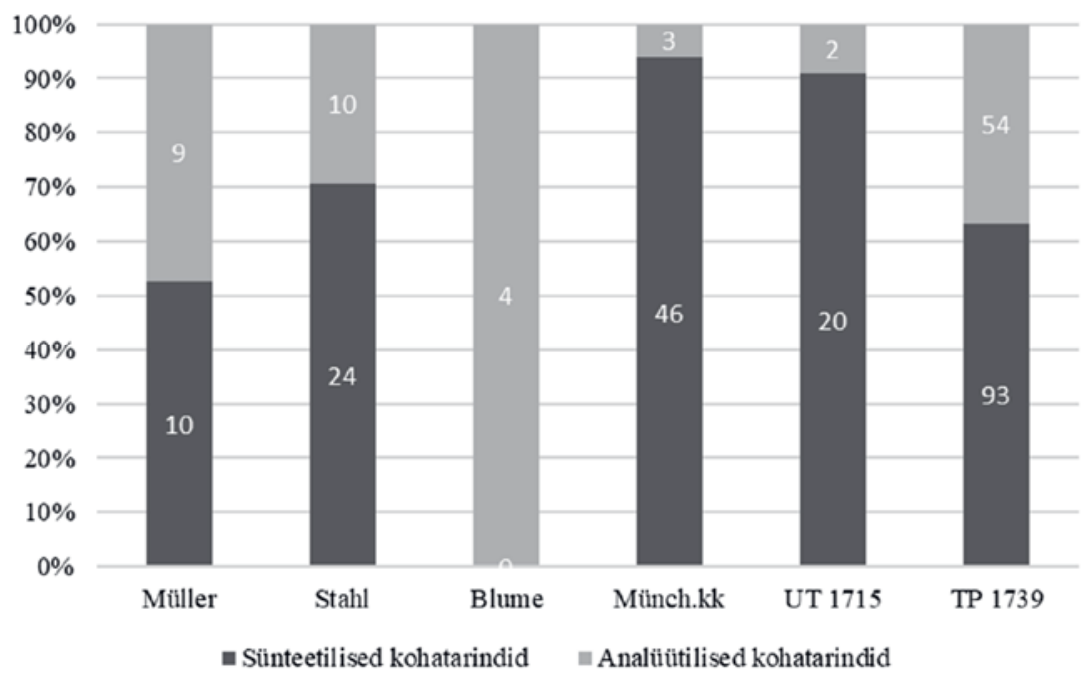

Joonis 3. Sõna linn asukohatähenduse väljendamise suhe

Peale sõna linn tõusid sünteetilisusele kalduvate kohatarindite seast esile ka sõnaga Jeruusalemm sihtkohta märkivad tarindid (vt joonist 4). Kõik autorid, kes väljendasid sõnaga Jeruusalemm sihtkohta, eelistasid sünteetilist sihtkohatarindit, mis osutab juurdunud kasutusviisile. 17. sajandi põhjaeesti kirjameestest märkis sihtkohta sõnaga Jeruusalemm Stahl, kes kasutas selle sõnaga põhiliselt sünteetilisi konstruktsioone ( $76 \%$ juhtudest), nagu ta oli seda teinud sõnaga linn moodustatud asukohakonstruktsioonide korral. 17. sajandi algupoole autori Mülleri ega sama sajandi keskpaiga kirjamehe Blume tekstides ei ilmnenud sõnaga Jeruusalemm moodustatud sihtkohatarindit. Müller kasutas selle asemel analüütilist konstruktsiooni Jeruusalemma linna sisse (vt nt VAKK, Müller5 1601: 5) ning Blume materjalis selle sõnaga sihtkohakonstruktsioonid puudusid. Blume tekstides leidus sõna Jeruusalemm vaid 22 korral, kuid teistes käänetes, väljendades nt asukohta (vt nt VAKK, Blume 1667: 122). Asukohta märkivad sünteetilised tarindid sõna Jeruusalemm puhul olid olemas ka Mülleri jutlustes (vt nt VAKK, Müller1 1600: 1).

18. sajandi põhjaeesti teostes leidus kohanimega Jeruusalemm sihtkohakonstruktsioone kõigis uuritud tekstides, kus sünteetiliste kohakonstruktsioonide osakaal jäi vahemikku 96-99\% ning oli võrreldes Stahli kasutatud sihtkohavormidega suurenenud ligikaudu $20 \%$. 


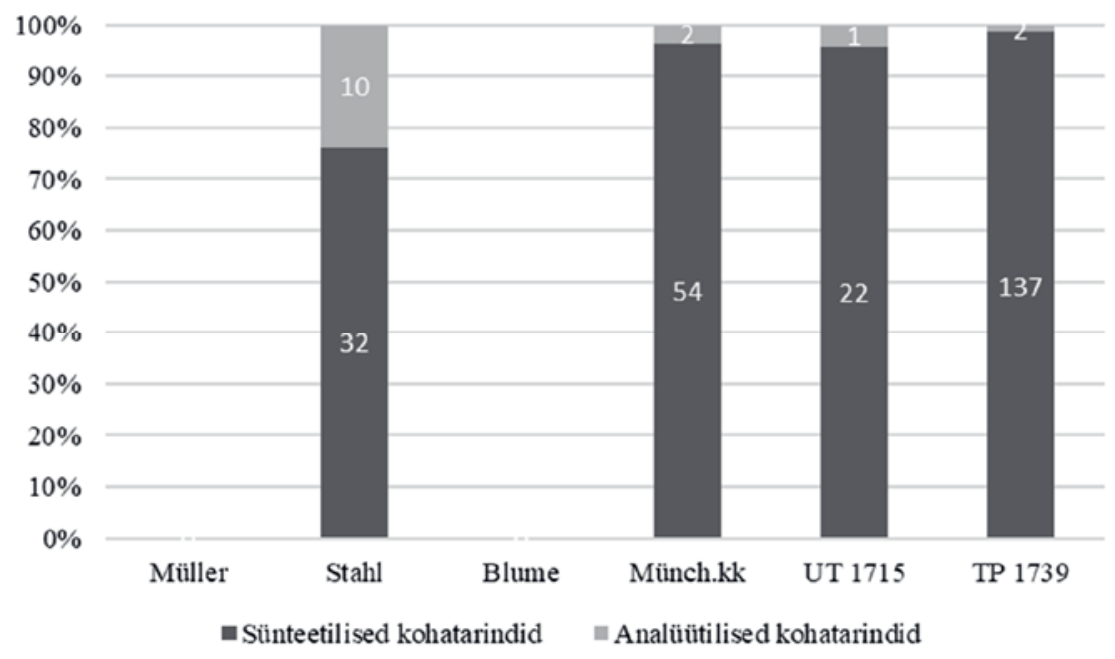

Joonis 4. Sõna Jeruusalemm sihtkohatähenduse väljendamise suhe

Kõigi siinses osas käsitletud substantiivides toimus selgem muutus kohta väljendavate tarindite vahekorras alates põhjaeesti kirjakeele reformi algusajast, 17. sajandi lõpukümnenditest. Kasutusmuutuse põhjus võib seisneda kirjakeele reformimise ja uuendusmeelsete kirjakeele arendajate mõjus. Muutuse algus kattub ajaga, mil toimusid laiemad keelevaidlused ja hakati kujundama tollast keeleideaali (Ross 2009: 556). Uuendusi pooldavate kirjameeste hulka kuuluv Johann Hornung ja pietistlikest põhimõtetest (rahvakeelsus, ühtsus ja selgus) lähtudes piibli toimetamist juhtinud Anton Thor Helle (Ross 2009: 556-557) oma keelekäsitluses kaassõnaliste tarindite võõrapärasusele otsesõnu aga ei osutanud (vt Hornung 1693; Helle jt 1732). See on ka loomulik, kuna nad on saksa päritolu ega pidanud analüütilisi kohatarindeid võõraks. Saksaeeskujuliseks või võõrapäraseks jooneks hakati kaassõnalisi tarindeid pidama 20. sajandi algupoolel, puristlike hoiakute levimise ajal (vt nt Aavik 1936: 92), mil tegeleti aktiivselt eesti keele arendamisega (vt nt Raag 2008: al 135). Samas viitab siinses osas vaadeldud kaheksa kohakonstruktsiooni sünteetilisuse järsk kasv koha väljendamisel, et selline kasutusmuutus ei olnud juhuslik ning kohta väljendavate sünteetiliste konstruktsioonide laiemale tarvitamisele võisid uuendusmeelseid autoreid suunata tähelepanekud rahvakeele kohta, samuti eespool mainitud ühtsuspõhimõttest lähtumine. 
Et uurida, kas suund sünteetilisuse poole esineb siinses osas vaadeldud sõnades ka järgmistel sajanditel või oli tegu ühele ajastule omase muutusega, tehti korpusotsing kõigi siin käsitletud sõnade kohta VAKKi 19. sajandi tekstidest ja tänapäevaseid veebitekste sisaldavast korpusest etTenTen. Korpusotsing näitas, et sünteetiline väljendus domineerib siin vaadeldud kaheksa substantiiviga kohatarindites nii 19. sajandil kui ka tänapäeval, nt sõnaga linn leidus sünteetilisi asukohatarindeid 19. sajandi tekstides $97,6 \%$ juhtudest (247 kasutuskorda) ja etTenTenis 99,8\% juhtudest (35 602 kasutuskorda), kuid analüütilisi tarindeid oli vastavalt vaid 2,4\% (6 kasutuskorda) ning 0,2\% juhtudest (94 kasutuskorda) (VAKK; etTenTen).

Sünteetiliste tarindite jätkuv eelistamine siinses osas vaadeldud sõnade puhul nii 19. sajandi kui ka tänapäevastes tekstides võib tuleneda aja jooksul kinnistunud kasutusviisist. 20. sajandist alates on sünteetilise kasutuse püsimisele kirjakeele tekstides ilmselt kaasa aidanud ka analüütiliste konstruktsioonide kui võõrapäraste taunimine ja soovitus asendada need sünteetilistega (vt nt Aavik 1936: 92; Palmeos 1985: 15, 21).

\subsection{Analüütilisusele kalduvad kohatarindid}

Uuritud 11 sõnast kaldus kohatähenduse väljendamisel analüütilisusele kolm: mägi, tee ja haud. Sõnaga mägi tarindites uuriti sihtkohatähenduse samaaegset väljendamist adpositsiooniga peale ja allatiiviga, sõnaga tee asukohatähenduse väljendamist adpositsiooniga peal ja adessiiviga ning sõnaga haud tarindites lähtekohatähenduse samaaegset väljendamist adpositsiooniga seest ja elatiiviga. Tabel 2 pakub ülevaadet nende substantiivide sise- ja väliskohakäänete ning kaassõnade vahekorrast kohatähenduse väljendamisel.

Tabel 2. Sise- ja väliskohakäänete ning kaassõnade vahekord analüütilisusele kalduvates sõnades

\begin{tabular}{|c|c|c|c|c|c|c|}
\hline Sõna & Funktsioon & Kääne & Sagedus & Kaassõna & Sagedus & Kokku \\
\hline mägi & Sihtkoht & Illatiiv & 7 & sisse & 27 & $\mathbf{3 4}$ \\
& & Allatiiv & 47 & peale & 106 & $\mathbf{1 5 3}$ \\
\hline tee & Asukoht & Inessiiv & 0 & sees & 1 & $\mathbf{1}$ \\
& & Adessiiv & 10 & peal & 294 & $\mathbf{3 0 4}$ \\
\hline haud & Lähtekoht & Elatiiv & 42 & seest & 15 & $\mathbf{5 7}$ \\
& & Ablatiiv & 1 & pealt & 2 & $\mathbf{3}$ \\
\hline
\end{tabular}


Joonisel 5 on esitatud vaadeldud analüütiliste ja sünteetiliste kohatarindite osakaal kolme sõna peale kokku. Siin ja edaspidi (sh joonistel) käsitletakse ainult nende paralleelsete käände-kaassõna paaridega moodustatud kohatarindeid, mille korral esines analüütiliste ja sünteetiliste vormide suhte vaatlemiseks piisavalt võrdlusmaterjali, nt sõna tee puhul vaid adessiivi ja adpositsiooniga peal moodustatud kohatarindid.

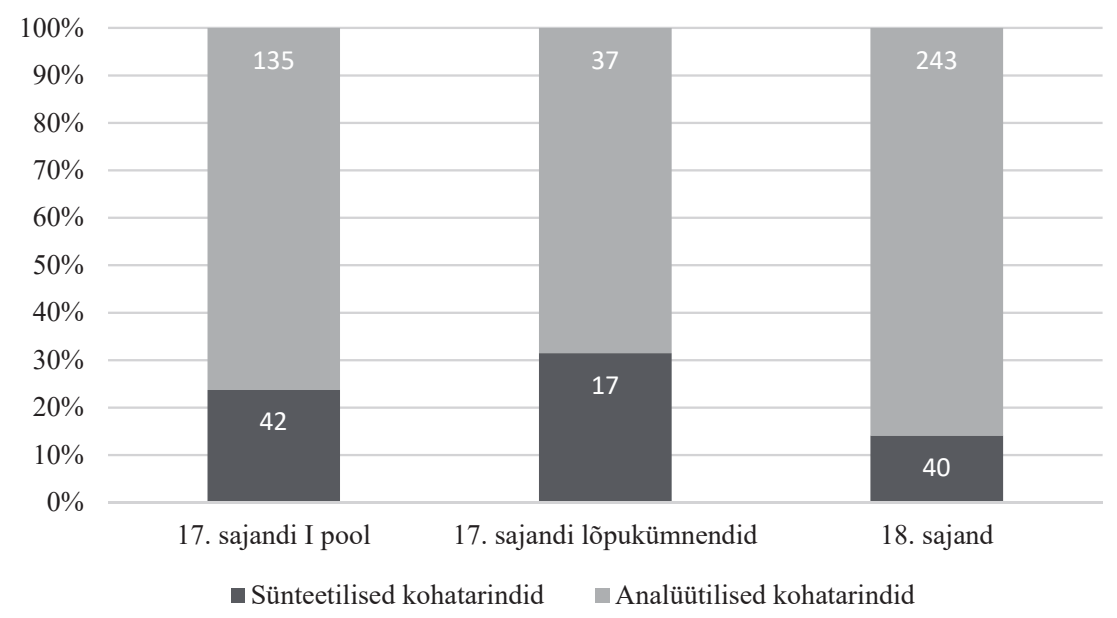

Joonis 5. Analüütiliste ja sünteetiliste vormide suhe analüütilisusele kalduvates kohatarindites

Uuritud ajajärgul olid nende sõnade puhul kokkuvõttes ülekaalus analüütilised tarindid (4). 17. sajandi I poole põhjaeesti tekstides moodustasid analüütilised konstruktsioonid 76\%, 17. sajandi lõpukümnenditel 69\% ja 18. sajandil $86 \%$ juhtudest. Kohta märkivate sünteetiliste tarindite osatähtsus oli vastavalt 24\%, 31\% ja 14\% (5).

(4) .. nedsamat eb olle mitte se eike Teh peel, muito nomat keuwat se kuria Te pael, kumb noemat iohata\{wat\}b, se Pörgkuhauwa sisse.. 'needsamad ei ole õige tee peal, vaid käivad kurjal teel, mis juhatab neid põrguhauda' (VAKK, Müller16 1604: 7)

(5) Agga kui temma sedda Rahwast näggi / läks temma ülles ühhe Mäle / ja istus mahha / ja temma Jüngrid tullid temma jure. (VAKK, UT 1715: $\mathrm{Mt}[\mathrm{V}]$ 1) 
Sõnu eraldi vaadates eristus mõnevõrra kõikuvama analüütilise kasutusega sõna haud (vt joonist 6). 17. sajandi I poole autorid Müller ja Stahl kasutasid sõna haud puhul ainult sünteetilisi lähtekohatarindeid, kuid siht- ja asukohta eelistasid mõlemad väljendada analüütiliste tarinditega (6). Seejuures ei esinenud Mülleri jutlustes sõna haud puhul ühtegi sünteetilise tarindiga väljendatud siht- ega asukohatähendust. Siinse uurimuse tulemused kinnitavad ka Rossi väidet, et Mülleri jutlustes ei esine adpositsiooni seest (Ross 1997: 189): peale sõna haud ei ilmnenud Mülleri jutlustest ka ülejäänud uuritud kümne sõna puhul ühtegi adpositsiooniga seest väljendatud kohatarindit.

17. sajandi keskpaigast hakati põhjaeesti tekstides substantiiviga haud moodustama analüütilisi kohatarindeid, mille osakaal kõikus mõneti 18. sajandi I pooleni, mil ilmus 1739. aasta täispiibel (7), tollase kirjakeele reformi tähtteos (Ross 2009: 557). 1739. aasta täispiiblis ei ole 1715. aasta uue testamendiga kokkulangevates lausetes sünteetilisi vorme analüütilistega siiski asendatud.

(6) Christus on sesamma Jho / kumb hauwa sisse pantut olli / sest hauwast tohnut; Agkas temma on paljo körgkemb ninck parramb ehhitut olnut I kus temma sest hauwast ülleßtousnut .. 'Kristus on sellesama ihu, mis hauda oli pandud, hauast välja toonud, aga tema on olnud palju kõrgem ning paremini ehitud, kui ta hauast üles tõusis' (VAKK, Stahl 1641: 441)

(7) Agga sind on ärrawissatud om ast hauast kui hirmus wösso, kui nende ärratappetud rie, kes moögaga läbbipistetud .. (VAKK, TP 1739: Js [XIV] 19)

Uurimusest ei ilmnenud, et analüütilisusele kalduvates kohatarindites oleks sõnadega mägi, tee ja haud toimunud alates kirjakeele reformi algusajast, 17. sajandi lõpukümnenditest ühtlast kasutusmuutust (8) (vt joonist 5, vrd 3.1). Sõnadega mägi ja tee tarindites domineeris ka 1694. aasta Müncheni käsikirjas jätkuvalt analüütiline kasutus, sõna haud puhul lisandusid analüütilised kohatarindid põhjaeesti tekstidesse 17. sajandi keskpaigast ning jäid valitsema 1739. aasta täispiiblis. Samas selgus, et sõna mägi puhul lisandusid sihtkohta väljendavad sünteetilised konstruktsioonid just alates keelereformi algusajast. Sama ilmnes substantiiviga mägi tarindites ka lähtekoha edasiandmisel. Samuti võis märgata sünteetiliste kohatarindite lisandumist või nende osakaalu suurenemist kirjakeele reformi algusajast alates sõnaga tee siht- ja lähtekohta ning sõnaga haud sihtkohta 


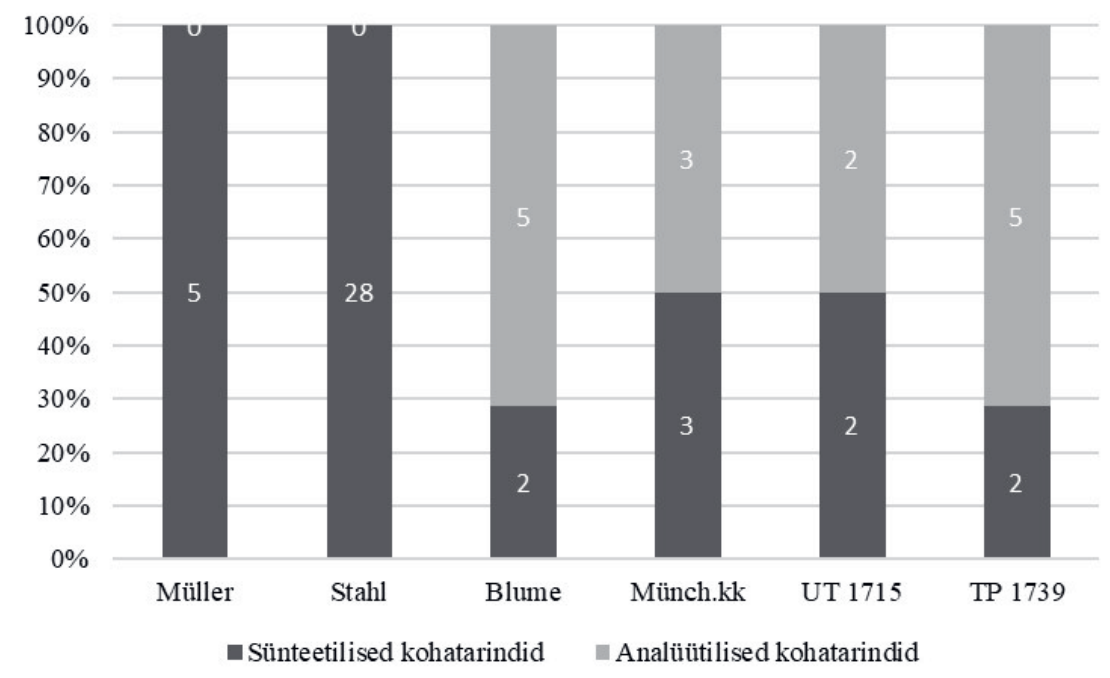

Joonis 6. Sõna haud lähtekohatähenduse väljendamise suhe

märkivates tarindites. See võib osutada kirjakeele reformi mõjule, mida näitab ka nende substantiivide sünteetiliste konstruktsioonide puudumine reformieelsel ajal.

(8) Ning kue päwa pärrast wottis Jesus ennesega Petrust ning Jakobi; ning Johannesse temma wenna ja wis nemmad issipäine ühhe körge Mä päle. (EPAK, Münch.kk 1694: Mt 17:1)

Sõnaga tee tarindites ilmnes, et 17. sajandi keskpaiga põhjaeesti autori Blume (9) tekstides oli sünteetiliste kohatarindite osakaal teiste uuritud 17.-18. sajandi põhjaeesti kirjameeste teostega võrreldes ligikaudu kaks korda suurem. See võib tuleneda väiksemast andmete koguhulgast, nt sõnaga tee moodustatud sünteetilisi ja analüütilisi kohatarindeid leidus Blume tekstides kokku 13 näidet, kuid Stahlil 81 näidet. Samas oli absoluutarvudes näiteid sõnaga tee asukohatarindite kohta kokku vähe ka mahukamates tekstides, nt Mülleri jutlustes (20 näidet) ja 1715. aasta uues testamendis (13 näidet). ${ }^{8}$ Samuti esines substantiiviga tee moodustatud sünteetilisi asukohatarindeid analüütiliste tarinditega võrreldes vähe kõigil vaadeldud autoritel, nt Stahli teostes kokku kaks näidet ja 1739.

\footnotetext{
${ }^{8}$ Mülleri jutluste ja 1715. aasta uue testamendi sõnede täpset arvu vt osast 2.
} 
aasta täispiiblis üks näide. Seega ei saa öelda, et sõna tee analüütiliste ja sünteetiliste kohatarindite suhet ei saaks võrrelda.

(9) \# ET Pehwlik lebbi Taiwa \# on johxnut Talwe Têel / \# on temma ilma Waiwa /\# lehp hilluk üllewel /.. 'et päike läbi taeva on jooksnud talveteel, on tema ilma vaevata, läheb hilju üles' (VAKK, Blume 1667: 44)

Blume võis võtta sõna tee sünteetilised asukohakonstruktsioonid kasutusele parema riimilise sobivuse tõttu. Kõik kolm sünteetilist asukohatarindit esinesid Blume kahe hilisema teksti „Geistliche Wochen-Arbeit“"(1666) ja „Geistliche Hohe Fäst-Tahgs Freude“ (1667) lauludes (VAKK). Laulude roll Blume tekstides uute ja/või vähem kasutatud vormide tarvitusele võtmisel on ilmnenud ka nt eituse väljendamisel (vt Pärismaa 2018). See võib osutada, et parema riimi otsimine lauludes võis soodustada selliste vormide kasutamist.

Kohakaassõnaga väljendatud analüütiliste tarindite domineerimine sõnade mägi, tee ja haud puhul võib tuleneda saksa keele mõjust. Tollal oli tavaline, et saksa keele eessõnalised konstruktsioonid tõlgiti eesti keeles tagasõnalisteks, mitte käändevormideks (Habicht 2000: 23), nt .. gieng hinauff auff einen Berg 'lex ülles mehje pehle' (VAKK, Stahl 1641: 334). Keelekontakti mõjutustele on osutanud ka nt Andrei Danchev (1992: 36). Samuti viitab analüütilise kohatarindi prevaleerimine (vt joonist 5), et just see kasutusviis oli nende sõnade korral kinnistunud.

Kuna sõnade mägi, tee ja haud korral ei avaldu selge suundumus sünteetilisuse poole, osutab see asjaolule, et tollased autorid ei tajunud kaassõnalisi kohatarindeid võõrapärasena, mida oleks vaja muuta, erinevalt nt saama-tulevikust (vt nt Kilgi 2011: 98-99). Eristati kaassõnade ja käändevormide täpsusastet (vt Göseken 1660: 71), kuid tollastes põhjaeesti grammatikates ei ole kirjas (vt nt Hornung 1693; Helle jt 1732), et analüütilised kohakonstruktsioonid tuleks asendada mõne rahvapärasema konstruktsiooniga. Ühelt poolt võib see olla mõjutatud selle aja autorite saksa päritolust, kuid teisalt võib põhjus olla, et postpositsioonid olid olemas ka tollases rahvakeeles, millele viitab nende esinemine eesti murretes (Palmeos 1985: 15, 21) ja kõigis läänemeresoome keeltes (Grünthal 2005: 31). Samas näitab sünteetiliste kohatarindite mõnetine lisandumine kirjakeele reformi algusajast alates, et täielikult mõjutamata ei jäänud kirjakeele reformist ka sõnadega mägi, tee ja haud kohatarindid. 
Otsing VAKKi 19. sajandi tekstide korpusest ja korpusest etTenTen näitas, et sõnadega mägi ja haud väljendatud kohatarindid pole aja jooksul analüütilisemaks muutunud. Nii 19. sajandi tekstides kui ka tänapäevastes veebitekstides domineeris nende kahe sõnaga kohakonstruktsioonides sünteetiline kasutus. Näiteks hõlmasid sõnaga mägi moodustatud sünteetilised sihtkohatarindid 19. sajandi tekstides 69,7\% kasutusjuhtudest (23 esinemiskorda) ja korpuses etTenTen 95\% kasutusjuhtudest (1472 esinemiskorda), samal ajal kui analüütilist kohakasutust esines selle substantiiviga tarindites vastavalt 30,3\% (10 esinemiskorda) ja 5\% kasutusjuhtudest (78 esinemiskorda). Sõna tee puhul prevaleerisid 19. sajandi tekstides analüütilised asukohakonstruktsioonid, kuid tänapäevastes tekstides sünteetilised konstruktsioonid.

19. sajandi tekstides ilmnenud kasutuspööre sõnadega mägi ja haud moodustatud kohatarindites võib olla mõjutatud kohatähenduse väljendamise üldisest suundumusest sünteetilise kasutuse ja ühtlustumise poole. Sellele osutab ka sünteetiliste kohatarindite prevaleerimine 19. sajandi tekstides, nagu ilmnes siinse artikli osas 3.1 uuritud substantiivide analüüsist. Oma mõju on ilmselt ka tekstiliigil. Artiklis uuritud VAKKi 17. sajandi ja 18. sajandi I poole põhjaeesti tekstid on vaimulikud, kuid 19. sajandi tekstid ilmalikud (nt jutukirjandus) ning sisaldavad kohtuprotokolle, kus keelekasutus on vabam ja rahvapärasem. Sõnaga tee moodustatud kohakonstruktsioonides võib eeldada varasema kasutustava jätkumist. Sünteetilise kasutuse domineerimine tänapäevastes tekstides on arvatavasti mõjutatud soovist tõrjuda analüütilisi kohatarindeid kui saksapäraseid ja soosida 20. sajandil sünteetilisi kui rahvapäraseid tarindeid (vt nt Aavik 1936: 92; Palmeos 1985: 15, 21). See on võinud mõju avaldada kohatähenduse väljendamisele ka 21. sajandi tekstides, nt korpuse etTenTen tekstides.

\section{Kokkuvõte}

Artiklis käsitleti kohatähenduse paralleelset analüütilist ja sünteetilist edasiandmist eesti vanemas kirjakeeles üheteistkümne sõna (mägi, tee, linn, haud, meri, Jeruusalemm, süda, taevas, raamat, kõrb, maa) näitel. Artikkel moodustab ühe osa morfosüntaktilisi nähtusi käsitlevast laiemast uurimusest, kus selgitatakse 17.-18. sajandi põhjaeesti kirjakeeles toimunud reformi kulgu ja iseloomustatakse ajajärku tervikuna. Seetõttu vaadeldi siinses artiklis, kas ja kuidas muutub kohatähenduse väljendamine 
17.-18. sajandi jooksul tollastes põhjaeesti kiriklikes tekstides. Eeldati, et alates põhjaeesti kirjakeele reformi algusajast, 17. sajandi lõpukümnenditest suureneb tekstides sünteetiliste kohatarindite osakaal. Oletati, et vähem analüütilisi kohatarindeid on ka uuendusmeelse autori Blume tekstides (vt nt Pärismaa 2018).

Üldjoontes võis uuritud ajajärgul märgata sünteetiliste kohatarindite domineerimist analüütiliste ees. Sama suundumus jätkus ka 19. sajandi ja tänapäeva tekstides. Sõnutigi ilmnes enamjaolt sarnane tendents. Üheteistkümnest sõnast kaheksa (meri, Jeruusalemm, süda, taevas, kõrb, raamat, linn, maa) kaldusid sünteetilisuse poole, milles võib näha tollase põhjaeesti kirjakeele reformi mõju. Teravam muutus kaassõnade ja käändevormidega moodustatud kohakonstruktsioonide vahekorras algab siinse materjali põhjal otsustades tollase põhjaeesti kirjakeele uuendamise algusajast, 1690. aastatest.

Kohatähenduse analüütilisele väljendamisele kaldusid üheteistkümnest sõnast kolm: sõnad mägi, tee ja haud. Nende substantiivide puhul domineerisid läbi terve 17. sajandi ja 18. sajandi I poole analüütilised kohatarindid. See tuleneb ilmselt tolleks ajaks välja kujunenud kasutustavast ja on võibolla mõjutatud ka saksa keelest kui tollasest peamisest kontaktkeelest. Samas ilmnes ka nende sõnadega kohatarindites mõningane kirjakeele reformi mõju - sellest ajast alates lisandus sünteetilisi vorme, nt sõnaga mägi kohatarindites sihtkoha väljendamisel.

Sünteetilisusele või analüütilisusele kaldumine ei olene sise- või väliskohakäänete ega kaassõnade kasutamisest. Siin uuritud sünteetilisusele kalduvad sõnad võisid kohatähendust märkida ka väliskohakäänetega või -kaassõnadega ning analüütilisusele kalduvad sõnad sisekohakäänete või -kaassõnadega. Kui aga autoriti kasutati käändeid või kaassõnu harva (nt ainult kaks autorit) või puudus emb-kumb paralleelse kohakasutuse paariline, siis ei saanud sellist kasutust arvestada. Näiteks märgiti sõna meri puhul adpositsiooniga peal asukohta, kuid adessiivne kasutus puudus. Sellised juhtumid jäeti kõrvale, kuna puudusid võrreldavad andmed, mis aitaksid selgitada kohatähenduse väljenduse muutumist aja jooksul.

Siinse uurimuse oletus analüütiliste kohatarindite vähenemise kohta Christoph Blume tekstides paika ei pidanud. Üheteistkümnest sõnast kaheksa (mägi, tee, linn, haud, meri, süda, taevas, raamat) puhul prevaleerisid Blume teostes analüütilised kohakonstruktsioonid, mis on tingitud ilmselt saksa keele eeskujust. Sõnaga Jeruusalemm tarindites 
ei ole ta kohatähendust väljendanud, sõna kõrb puhul oli analüütilisi ja sünteetilisi kohatarindeid võrdselt ning vaid sõnaga maa tarindites leidus tal üks sünteetiline vorm, kuid mitte ühtegi analüütilist. Samas oli Blume tekstides sõnaga tee moodustatud sünteetiliste asukohakonstruktsioonide osakaal mõnevõrra suurem teiste 17.-18. sajandi põhjaeesti autorite tekstide omast. Kõik need asukohatarindid esinesid tema teoste lauludes. Uuenduslike ja/või vähem levinud vormide tarvitamine lauludes võib viidata, et lauludele tuleks Blume keelekasutuse jälgimisel eraldi tähelepanu pöörata, sest sealne riimi taotlus võis soodustada uute ja/või vähem levinud vormide kasutuselevõttu.

\section{Lühendid}

Js - Jesaja raamat; $1 \mathrm{Kr}$ - Pauluse 1. kiri korintlastele; $\mathrm{Mt}$ - Matteuse evangeelium

\section{Kirjandus}

Aavik, Johannes 1936. Eesti õigekeelsuse õpik ja grammatika. Tartu: NoorEesti Kirjastus.

Barlow, Michael, Suzanne Kemmer (eds.) 2000. Usage Based Models of Language. Stanford: CSLI Publications.

Bybee, Joan 2010. Language, Usage and Cognition. Cambridge: Cambridge University Press. http://dx.doi.org/10.1017/CBO9780511750526

Danchev, Andrei 1992. The evidence for analytic and synthetic developments in English. - History of Englishes: New Methods and Interpretations in Historical Linguistics. Ed. by Matti Rissanen, Ossi Ihalainen, Terttu Nevalainen, Irma Taavitsainen. Berlin: Mouton de Gruyter, 25-41. http:// dx.doi.org/10.1515/9783110877007.25

Grünthal, Riho 2005. Miksi itämerensuomessa on prepositioita? - Virittäjä 1, $28-51$.

Göseken, Heinrich 1660. Manuductio ad Linguam Oesthonicam. Reval: A. Simon. http://www2.kirmus.ee/grafo/index.php?ID=243 (12.03.2020)

Habicht, Külli 2000. Grammaticalization of adpositions in Old Literary Estonian. - Estonian: Typological Studies IV. Ed. By Mati Erelt. Tartu: Tartu University Press, 19-58.

Habicht, Külli 2001. Eesti vanema kirjakeele leksikaalsest ja morfosüntaktilisest arengust ning Heinrich Stahli keele eripärast selle taustal. (= Dissertationes philologiae estonicae Universitatis Tartuensis 10.) Tartu: Tartu Ülikooli Kirjastus. 
Habicht, Külli, Helle Metslang 2015. Tea kus see kirjamees siiani elanud on, kuu peal või Marsil? Analüütilisusest ja sünteetilisusest eri aegade kirjakeeles. Ettekanne 11. muutuva keele päeval, 6. novembril 2015. http:// kimovar.ut.ee/?page_id=322 (09.03.2020)

Helle jt $\mathbf{1 7 3 2}$ = Anton Thor Helle 1732. Kurtzgefaszte Anweisung Zur Ehstnischen Sprache. Halle: Stephan Orban. https://www.digar.ee/arhiiv/ nlib-digar:100071 (12.03.2020).

Hornung, Johann 1693. Grammatica Esthonica, brevi, Perspicua tamen methodo ad Dialectum Revaliensem. Riga: Literis Joh. Georg Wilck. https:// dspace.ut.ee/handle/10062/9996 (12.03.2020).

Kilgi, Annika 2011. Anton Thor Helle toimetajakäekiri: kuidas Thor Helle vana testamendi verbimorfoloogiat redigeeris. - Emakeele Seltsi aastaraamat 56 (2010). Peatoim. Mati Erelt. Tallinn: Teaduste Akadeemia Kirjastus, 91-108. doi:10.3176/esa56.04

Kilgi, Annika 2012. Eitusvormid 17.-18. sajandi eesti piibliversioonides. (= Tallinna Ülikooli eesti keele ja kultuuri instituudi toimetised 13.) Tallinn: Tallinna Ülikool, 106-137.

Kingisepp jt 2010 = Valve-Liivi Kingisepp, Kristel Ress, Kai Tafenau 2010. Heinrich Gösekeni grammatika ja sõnastik 350. Tartu: Tartu Ülikool.

Lill, Anne 1988. Christoph Blume ja XVII sajandi eesti kirjakeel. - Keel ja Kirjandus 1, 7-17.

Metslang, Helle 1994. Eesti ja soome - futuurumita keeled? - Keel ja Kirjandus 9, 534-547.

Metslang jt 2017 = Helle Metslang, Külli Habicht, Tiit Hennoste, Anni Jürine, Kirsi Laanesoo, David Ogren 2017. Komitatiivi funktsioonidest eri aegade ja registrite eesti kirjakeeles. - Eesti ja soome-ugri keeleteaduse ajakiri / Journal of Estonian and Finno-Ugric Linguistics 8 (1), 149-178. http://dx.doi.org/10.12697/jeful.2017.8.1.09

Palmeos, Pauline 1985. Eesti keele grammatika. II osa. Neljas vihik. Kaassõna (kolmas trükk). Tartu: Tartu Riiklik Ülikool.

Pärismaa, Liina 2016. Christoph Blume keelekasutuse eripärast. Magistritöö. Tartu: Tartu Ülikool. https://dspace.ut.ee/handle/10062/51754 (09.03.2020).

Pärismaa, Liina 2018. Eituse väljendamise vormivalikutest XVII-XVIII sajandi põhjaeesti tekstides. - Keel ja Kirjandus 7, 560-578.

Pärismaa, Liina 2019. Analüütilised tulevikutarindid 17.-18. sajandi põhjaeesti kirjakeeles. - Emakeele Seltsi aastaraamat 64 (2018). Peatoim. Mati Erelt. Tallinn: Teaduste Akadeemia Kirjastus, 141-167. http://dx.doi. org/10.3176/esa64.05

Raag, Raimo 2008. Talurahva keelest riigikeeleks. Tartu: Atlex. 
Reila, Heiki 2007. Müncheni käsikirjast ja selle seostest Johann Hornungi tõlkega: keelelisi tähelepanekuid. - Põhjaeestikeelsed Uue Testamendi tõlked 1680-1705. Toim. Heiki Reila, Kristiina Ross, Kai Tafenau. Tallinn: Eesti Keele Sihtasutus, 556-563.

Ross, Kristiina 1997. Kohakäänded Georg Mülleri ja Heinrich Stahli eesti keeles. - Pühendusteos Huno Rätsepale. (= Tartu Ülikooli eesti keele õppetooli toimetised 7). Tartu: Tartu Ülikooli Kirjastus, 184-201.

Ross, Kristiina 2009. Eesti keel Henrikust Anton Thor Helleni. - Keel ja Kirjandus 8-9, 553-558.

Ross, Kristiina 2013. Vanad uuendused lõuna- ja põhjaeesti keeles. - Emakeele Seltsi aastaraamat 58 (2012). Peatoim. Mati Erelt. Tallinn: Teaduste Akadeemia Kirjastus, 210-223. http://dx.doi.org/10.3176/esa58.10

Rätsep, Huno 1987. Heinrich Stahli keeleõpetus oma aja peeglis. - Keel ja Kirjandus 12, 709-715.

Stahl, Heinrich 1637. Anführung zu der Esthnischen Sprach, auff Wolgemeinten Rath, und Bittliches Ersuchen. Reval: H. Stahl. https://www.digar.ee/ arhiiv/nlib-digar:101060 (12.03.2020).

Ziegelmann, Katja, Eberhard Winkler 2006. Zum Einflu $\beta$ des Deutschen auf das Estnische. - Deutsch am Rande Europas. Tartu: Tartu University Press, 43-70.

Veismann, Ann, Mati Erelt 2017. Kaassõnafraas. - Eesti keele süntaks. (= Eesti keele varamu III.) Toim. Mati Erelt, Helle Metslang. Tartu: Tartu Ülikooli Kirjastus, 446-462.

\section{Korpused}

EPAK = Eesti piiblitõlke ajalooline konkordants. http://portaal.eki.ee/piibel (14.03.2020).

VAKK = Vana kirjakeele korpus. http://www.murre.ut.ee/vakkur/Korpused/ korpused.htm; http://vakk.ut.ee/ (16.03.2020).

etTenTen $=$ Eesti veeb 2013. http://keeleveeb.ee (16.03.2020). 


\title{
The relationship between analytic and synthetic locative constructions in the 17th and 18th century North Estonian literary language
}

\author{
LIINA PÄRISMAA
}

This article is part of a broader morphosyntactic study dealing with analytic and synthetic constructions expressing spatial relations in the 17th and 18th century North Estonian literary language. The aim of this study is to observe if and how the relationship between analytic and synthetic constructions changes during the two centuries in ecclesiastical texts. It is hypothesized that from the beginning of the literary language reform at the end of the 17th century, the proportion of synthetic constructions increases and that less analytic constructions can be seen in the texts of Christoph Blume, which were written in the middle of the 17th century.

This study is usage-based and the material originates from the corpora of Old Written Estonian and the Concordance of Estonian Bible Translations. The study focuses on the relationship of analytic and synthetic constructions in eleven nouns: mägi 'mountain', tee 'road', linn 'city', haud 'grave', meri 'sea', Jeruusalemm 'Jerusalem', süda 'heart', taevas 'heaven', raamat 'book', kõrb 'desert', and maa 'land'. These words were chosen based on the versatility of the forms expressing spatial relations, the existence of both members of the parallel expression of spatial relations, and frequency.

The results of this study show that generally the proportion of synthetic locative constructions increased (in eight nouns out of eleven) and the proportion of analytic locative constructions decreased, which could be due to the influence of the literary language reform and the reformers. The more abrupt change in the relationship between analytic and synthetic constructions took place from the end of the 17th century since the beginning of the literary language reform. The results did not indicate that the direction towards analytic or synthetic use depends on the use of internal or external local case or adpositions.

In the words mägi 'mountain', tee 'road' and haud 'grave' the analytic locative constructions dominated, which could be caused by the developed traditional marking manner and due to the German influence that was common at that time. Nevertheless, some synthetic locative constructions formed with those words occurred from the beginning of the literary language reform, which indicates that the literary language reform influenced those constructions as well. 
Blume did not use less analytic constructions to express spatial relations than any other author of that time. He used analytic constructions in eight words out of eleven: mägi 'mountain', tee 'road', linn 'city', haud 'grave', meri 'sea', süda 'heart', taevas 'heaven', raamat 'book', which could be due to the German influence. However, in the case of tee 'road' the proportion of synthetic forms in his texts, which all occurred in his songs, was somewhat higher than in other 17th and 18th century North Estonian authors' texts (see 3.2). This indicates that it is important to pay special attention to the songs in his texts, because they could have contributed to the adoption of new and/or less widespread forms.

Keywords: Old Written Estonian, morphosyntax, locative cases, locative adpositions, Estonian language

Liina Pärismaa

eesti ja üldkeeleteaduse instituut

Tartu Ülikool

Jakobi 2

51014 Tartu

liina.parismaa@ut.ee 